\title{
ANALISIS BERPIKIR KREATIF DALAM MENYELESAIKAN MASALAH BARISAN DAN DERET ARITMATIKA DENGAN METODE OPEN-ENDED
}

\author{
Lilis Setianingsih ${ }^{1}$, Bambang Priyo Darminto ${ }^{2}$ \\ lilissetianingsih2203@gmail.com, bambangpdc115@gmail.com \\ ${ }^{1,2}$ Universitas Muhammadiyah Purworejo
}

\begin{abstract}
This study aims to determine students creative thinking skills in solving arithmetic progression and series problems with the open-ended method. The research method used is a qualitative method with a case study approach. The selection of subjects uses a purposive technique that is based on certain characteristics. The subjects in this study were 3 junior high school students selected in the category of high matematical abilities. Methods of collecting data using tests, interviews, field notes, and documentation. Data analysis techniques used the triangulation method to gain deeper understanding of the subject under study. Based on the results of the study show the ability of creative thinking of students because it meets the three indicators of creative thinking, namely fluency: students are able to calculate smoothly and solve problems correctly, flexibility: students are able to find other ways to find the same results, novelty: students are able to think in new ways and different from other subjects.
\end{abstract}

Keywords: creative thinking, problem solving, open-ended

\section{Abstrak}

Penelitian ini bertujuan untuk mengetahui kemampuan berpikir kreatif siswa dalam menyelesaikan masalah barisan dan deret aritmatika dengan metode open-ended. Metode penelitian yang digunakan adalah metode kualitatif dengan pendekatan studi kasus. Pemilihan subjek menggunakan teknik purposive yaitu didasarkan atas ciri-ciri tertentu. Subjek dalam penelitian ini adalah 3 siswa kelas VIII SMP yang terpilih dalam kategori kemampuan matematika yang tinggi. Metode pengumpulan data menggunakan tes, wawancara, catatan lapangan dan dokumentasi. Teknik analisis data menggunakan metode triangulasi untuk mendapatkan pemahaman lebih dalam tentang subjek yang diteliti. Berdasarkan hasil penelitian, siswa menunjukkan kemampuan berpikir kreatif karena memenuhi tiga indikator berpikir kreatif, yaitu kelancaran:siswa mampu menghitung dengan lancar dan menyelesaikan masalah dengan benar, keluwesan: siswa mampu menemukan cara lain untuk menemukan hasil yang sama, kebaruan: siswa mampu berpikir dengan cara baru dan berbeda dengan subjek lain.

Kata kunci: berpikir kreatif, menyelesaikan masalah, open-ended

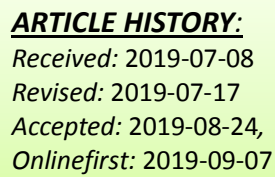




\section{PENDAHULUAN}

Dalam penggunaan kurikulum 2013 saat ini khususnya dalam pembelajaran matematika, kemampuan berpikir kreatif baik pada guru maupun pada siswa perlu ditingkatkan. Mrayyan (2016) mengatakan bahwa kreativitas adalah kemampuan untuk membayangkan atau menciptakan sesuatu yang baru, kreativitas bukanlah kemampuan untuk menciptakan apa-apa, tetapi kemampuan untuk menghasilkan ide-ide baru dengan menggabungkan, mengubah, atau mengaplikasikan kembali ide-ide yang sudah ada. Kreativitas juga merupakan sikap yang menunjukkan kemampuan untuk menerima perubahan dan kebaruan, bersedia untuk bergulat dengan ide-ide dan kemungkinankemungkinan. Orang yang kreatif cenderung meningkatkan ide-ide dalam menyelesaikan masalah, dengan merubah dan memperbaiki secara bertahap pada pekerjaan mereka. Pembelajaran dalam kurikulum 2013 perlu berpusat pada siswa, artinya siswa harus berperan lebih aktif dan berpikir secara mandiri dalam pembelajaran khususnya pembelajaran matematika untuk meningkatkan berpikir kreatifnya yang masih rendah.

Rendahnya berpikir kreatif siswa didukung oleh salah satu hasil penelitian dari Fardah (2012) yaitu berupa pola berpikir kreatif siswa kategori tinggi sebanyak 6 siswa (20\%), kategori sedang sebanyak 10 siswa $(33,33 \%)$, dan rendah sebanyak 14 siswa $(46,67 \%)$. Hal ini menunjukan bahwa tingkat berpikir kreatif siswa masih rendah, yaitu hampir 50\% siswa tingkat berpikir kreatifnya rendah, ditambah sekitar 30\% siswa memiliki tingkat berpikir kreatif sedang, hanya 20\% siswa yang memiliki tingkat berpikir kreatif tinggi.Fakta lain yang mendukung rendahnya berpikir kreatif siswa adalah salah satu hasil dari kompetensi matematika dan sains international yaitu Programme for International Student Assesment (PISA). Hasil PISA pada tahun 2015 menyatakan bahwa peringkat Indonesia naik tapi masih sangat rendah. Peringkat Indonesia naik dari peringkat 71 pada tahun 2012 menjadi 64 pada tahun 2015 dari 72 negara anggota Organization for Economic Cooperation and Development (OECD) (Mepnews, 2016).

Apabila saat ini berpikir kreatif siswa masih rendah, maka kurikulum 2013 dapat dikatakan belum diterapkan dengan baik. Oleh karena itu, guru perlu memilih model, strategi, atau pendekatan pembelajaran apa yang sesuai dengan karakter siswa-siswanya dan dapat meningkatkan kualitas proses belajar mengajar di dalam kelas. Salah satu 
pendekatan pembelajaran yang digunakan peneliti adalah pendekatan open-ended. Menurut Becker \& Shimada dalam Koriyah dkk (2015) menyebutkan bahwa openended adalah pendekatan pembelajaran yang diformulasikan untuk menyajikan masalah terbuka dengan penyelesaian atau jawaban benar lebih dari satu.

Pendekatan open-ended memberikan kesempatan kepada siswa untuk memperoleh pengetahuan atau pengalaman menemukan, mengenali dan memecahkan masalah dengan beberapa teknik. Pernyataan tersebut menunjukkan bahwa masalah open-ended dapat memunculkan berpikir kreatif pada siswa. Guru memberikan soal-soal yang dapat menumbuhkan kemampuan berpikir kreatif siswa yaitu dengan soal open-ended. Menurut Kang Sup (2003) merekomendasikan bahwa pemberian tes matematika berdasarkan masalah open-ended harus diperkenalkan di sekolah, karena dapat merangsang kreativitas matematika siswa dan pemikiran yang berbeda.

Dalam penyelesaian masalah open-ended, tidak hanya menerapkan dan mempraktikkan algoritma yang disajikan oleh guru, tetapi mendorong siswa untuk menantang masalah baru dan mengembangkan pemikiran yang fleksibel, karena masalah open-ended menyediakan lebih dari satu jawaban atau dalam kata lain soal yang mempunyai banyak cara penyelesaian yang benar. Dari uraian di atas, peneliti ingin mengetahui lebih dalam mengenai berpikir kreatif siswa dalam menyelesaikan masalah matematika menggunakan soal open-ended. Peneliti mengukur berpikir kreatif siswa menggunakan indikator menurut Silver dalam Firdausi dkk (2018) yaitu kefasihan (fluency), keluwesan (flexibility) dan kebaruan (novelty).

\section{METODE PENELITIAN}

Metode penelitian adalah penelitian kualitatif menggunakan pendekatan studi kasus. Penelitian dilaksanakan pada bulan Oktober 2018 sampai Mei 2019. Subjek penelitian dipilih menggunakan teknik purposive yaitu dengan pertimbangan tertentu (Sugiyono, 2012), berdasarkan nilai murni PTS matematika yang mendapatkan nilai >90. Instrumen penelitian merupakan alat bantu yang digunakan oleh peneliti untuk mengumpulkan data penelitian dengan cara melakukan pengukuran (Widoyoko, 2017). Sugiyono (2012) mengungkapkan bahwa peneliti kualitatif sebagai human instrument, berfungsi menetapkan fokus penelitian, memilih informan sebagai sumber data, melakukan pengumpulan data, menilai kualitas data, analisis data, menafsirkan data dan 
membuat kesimpulan atas temuannya.

Dalam penelitian ini, peneliti menggunakan instrumen pendukung pada pengumpulan data yaitu soal tes yang telah divalidasi oleh validator dengan maksud untuk menguatkan keabsahan instrumen, wawancara tidak terstruktur, dan catatan lapangan. Teknik pengumpulan data yang digunakan dalam penelitian ini dengan pemberian soal tes, melakukan wawancara, catatan lapangan dan dokumentasi berupa cuplikan hasil pekerjaan siswa. Teknik analisis data yang digunakan mengacu pada model Miles dan Huberman (Sugiyono, 2012) yaitu: (1) Data Reduction (Reduksi Data), (2) Data Display (Penyajian Data), (3) Conclusion Drawing/Verification (Penarikan Kesimpulan). Sedangkan teknik pemeriksaan keabsahan data yang digunakan yaitu (1) Uji credibilty, (2) Uji dependability (Sugiyono, 2012).

\section{HASIL DAN PEMBAHASAN}

Subjek dalam penelitian ini adalah siswa kelas VIII SMP yang mempunyai kemampuan matematika tinggi. Subjek yang telah terpilih diberikan soal tes barisan dan deret aritmatika. Pengamatan tentang kemampuan berpikir kreatif mengacu pada 3 bentuk data dalam kegiatan penelitian ini yaitu vignette berupa cuplikan hasil pekerjaan subjek, hasil wawancara dan hasil catatan lapangan. Tiga data ini akan menjadi tolok ukur peneliti dalam menyimpulkan bagaimana kemampuan berpikir kreatif siswa dalam menyelesaikan masalah barisan dan deret aritmatika melalui soal open-ended.

1. Pak Hadi sedang menumpuk batu bata yang tingginya 10 tingkat membentuk sebuah piramida. Pada tumpukan batu bata tersebut, banyak batu bata paling bawah ada 10 buah, tepat di atasnya ada 9 buah, dan seterusnya setiap tumpukan di atasnya selalu berkurang 1 buah dari jumlah batu bata di tingkat bawahnya. Berapa batu bata yang diperlukan Pak Hadi untuk membuat sebuah piramida? Sudah terjawab? Jika sudah, coba kerjakan dengan cara yang lain!

2. Rina menghitung banyaknya bilangan asli antara 1 sampai 100 yang habis dibagi 6. Berapa jumlah seluruh bilangan diantara 1 sampai 100 yang habis dibagi 6 ? Sudah terjawab? Jika sudah, coba kerjakan dengan cara yang lain!

Gambar 1. Soal barisan dan deret aritmatika dengan metode open-ended

Pada gambar tersebut, soal yang disajikan sebagai instrumen tes dalam penelitian ini telah didesain untuk memunculkan ide-ide kreatif para subjek penelitian. Soal barisan dan deret aritmatika dengan metode open-ended berarti soal tersebut mempunyai banyak jawaban yang benar, sehingga dapat memunculkan berpikir kreatif 
siswa. Hasil penyelesaian soal yang dilakukan subjek pertama $\left(S_{1}\right)$, subjek kedua $\left(S_{2}\right)$ dan subjek ketiga $\left(S_{3}\right)$ terlihat pada analisis berikut.

1. Subjek pertama $\left(S_{1}\right)$

Langkah pertama yang dilakukan oleh $S_{1}$ ketika menyelesaikan soal nomor 1 terlihat dari hasil pekerjaan berikut ini.

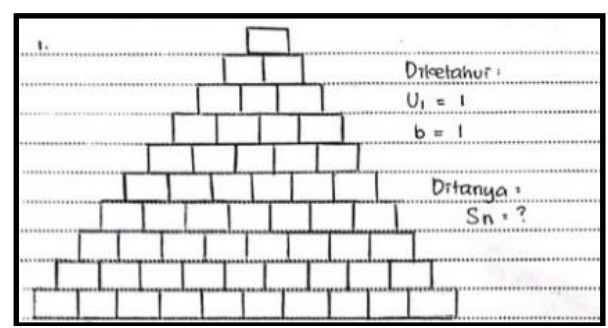

Gambar 2. $S_{1}$ memahami masalah

Dari gambar di atas, $S_{1}$ mampu menggambar piramida dengan benar dan mengetahui apa yang diketahui dan apa yang ditanyakan, sehingga $S_{1}$ dapat memahami masalah dengan baik. Selanjutnya, langkah kedua yang dilakukan $S_{1}$ yaitu menyelesaikan masalah menggunakan rumus. Hal ini terlihat dari hasil pekerjaan berikut ini.

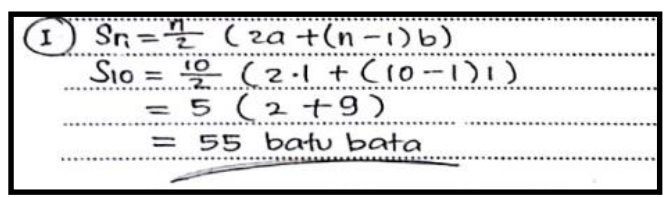

Gambar 3. $S_{1}$ menyelesaikan masalah dengan cara pertama

Dari gambar di atas, terlihat bahwa $S_{1}$ dapat menghubungkan data yang belum diketahui pada soal dengan baik dan menyelesaikannya sesuai rencana. Hasilnya tepat dan benar serta menghitung lancar, sehingga dapat dikatakan bahwa $S_{1}$ mampu menunjukkan indikator berpikir kreatif kefasihan (fluency) dalam menyelesaikan soal.

Langkah berikutnya yang dilakukan $S_{1}$ yaitu menggunakan cara lain untuk menyelesaikan soal. Hal ini terlihat dari hasil pekerjaan $S_{1}$ berikut ini.

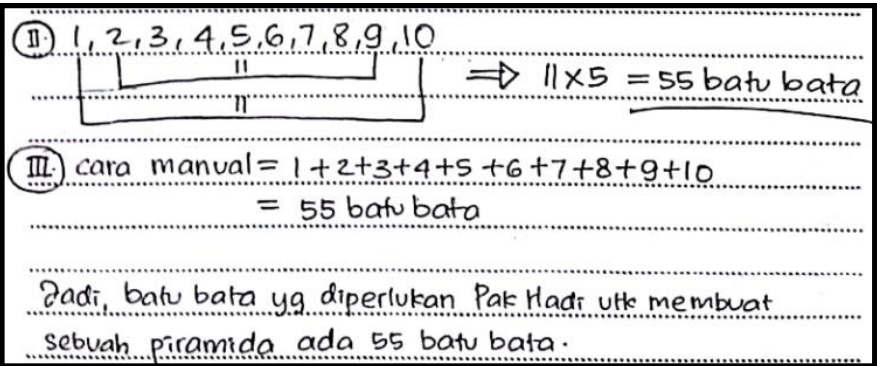

Gambar 4. $S_{1}$ menyelesaikan masalah dengan cara lain 
Dari gambar di atas, terlihat bahwa $S_{1}$ dapat menggunakan cara lain dan hasilnya sama dengan menyelesaikan soal dengan cara pertama, sehingga $S_{1}$ mampu menunjukkan indikator berpikir kreatif keluwesan (flexibility).

Langkah pertama yang dilakukan oleh $S_{1}$ ketika menyelesaikan soal nomor 2 terlihat dari hasil pekerjaan berikut ini.

\begin{tabular}{|c|c|}
\hline 2. Diketahur. & Ditanya: \\
$6,12,18, \ldots, 96$ & $S_{n}=?$
\end{tabular}

\section{Gambar 5. $S_{1}$ memahami masalah}

Dari gambar tersebut, $S_{1}$ memahami soal nomor 2 dengan menuliskan apa yang diketahui dan apa yang ditanyakan. Selanjutnya, $S_{1}$ menyelesaikan masalah cara pertama dengan mencari $n$ terlebih dahulu untuk menghitung $S_{n}$. Hal ini terlihat dari hasil pekerjaan berikut ini.

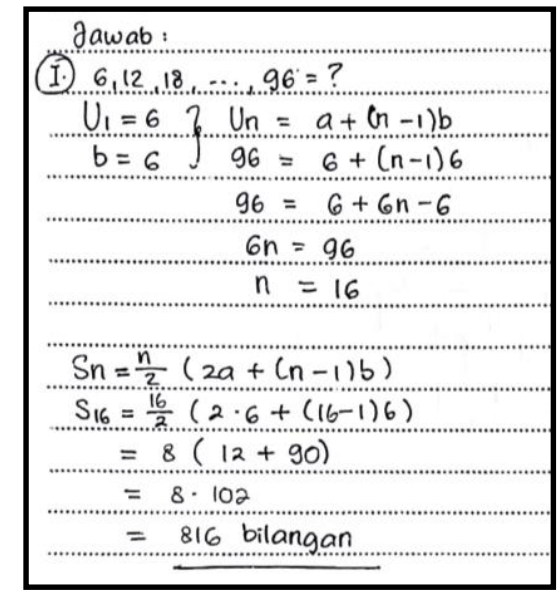

Gambar 6. $S_{1}$ menyelesaikan masalah dengan cara pertama

Berdasarkan gambar tersebut, hasil pekerjaan $S_{1}$ menunjukkan bahwa memperoleh nilai $n$ kemudian menghitung $\mathrm{S}_{\mathrm{n}}$ dengan tepat serta menghitung lancar, sehingga dapat dikatakan bahwa $S_{1}$ mampu menunjukkan kefasihan (fluency) dalam menyelesaikan soal. Langkah berikutnya yang dilakukan $S_{1}$ yaitu menggunakan cara lain untuk menyelesaikan soal. Hal ini terlihat dari hasil pekerjaan $S_{1}$ berikut ini.

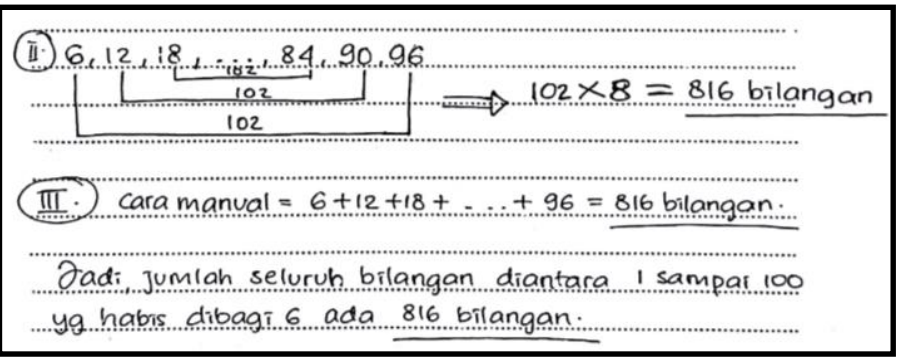

Gambar 7. $S_{1}$ menyelesaikan masalah dengan cara lain 
Dari gambar tersebut, terlihat bahwa $S_{1}$ dapat menggunakan cara lain untuk menyelesaikan soal dengan hasil yang sama. Setelah menyelesaikan soal dengan menghitung lancar dan dapat menggunakan cara lain dalam menyelesaikan soal dengan jawaban yang benar, maka $S_{1}$ memenuhi indikator kemampuan berpikir kreatif kefasihan (fluency) dan keluwesan (flexibility). Untuk indikator kemampuan berpikir kreatif kebaruan (novelty), $S_{1}$ belum dapat memenuhinya.

2. Subjek kedua $\left(S_{2}\right)$

Langkah pertama yang dilakukan oleh $S_{2}$ ketika menyelesaikan soal nomor 1 terlihat dari hasil pekerjaan berikut ini.

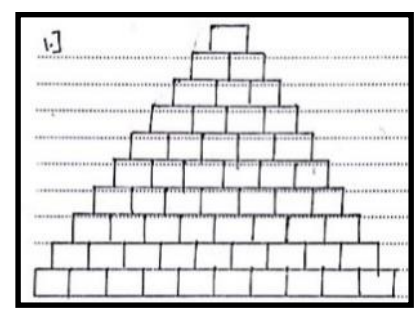

Gambar 8. $S_{2}$ memahami masalah

Dari gambar di atas, $S_{2}$ dapat dikatakan mampu memahami masalah dengan menggambar piramida. Tanpa menuliskan apa yang diketahui dan ditanyakan, langkah selanjutnya yang dilakukan oleh $S_{2}$ yaitu langsung menjawab alternatif 1 . Hal ini terlihat dari hasil pekerjaan berikut ini.

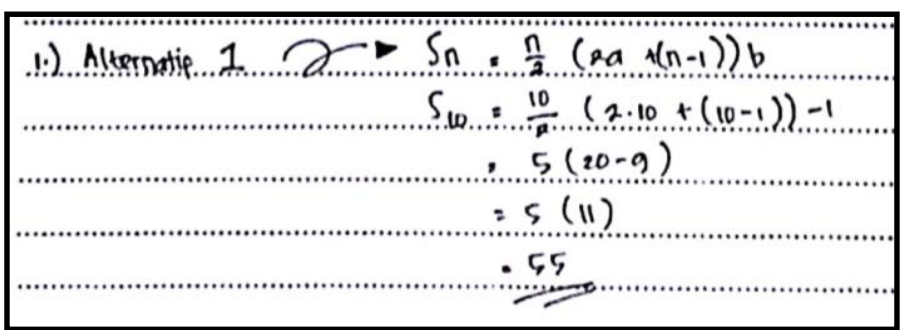

Gambar 9. $S_{2}$ menyelesaikan masalah dengan cara pertama

Berdasarkan gambar tersebut, terlihat bahwa $S_{2}$ dapat menghubungkan data yang belum diketahui pada soal dengan baik dan menyelesaikannya sesuai rencana. Hasil pekerjaanya tepat dan menghitung lancar, sehingga dapat dikatakan bahwa $S_{2}$ mampu menunjukkan indikator berpikir kreatif fluency dalam menyelesaikan soal. Langkah selanjutnya yang dilakukan $S_{2}$ adalah mencari alternatif jawaban lain, terlihat pada gambar berikut. 

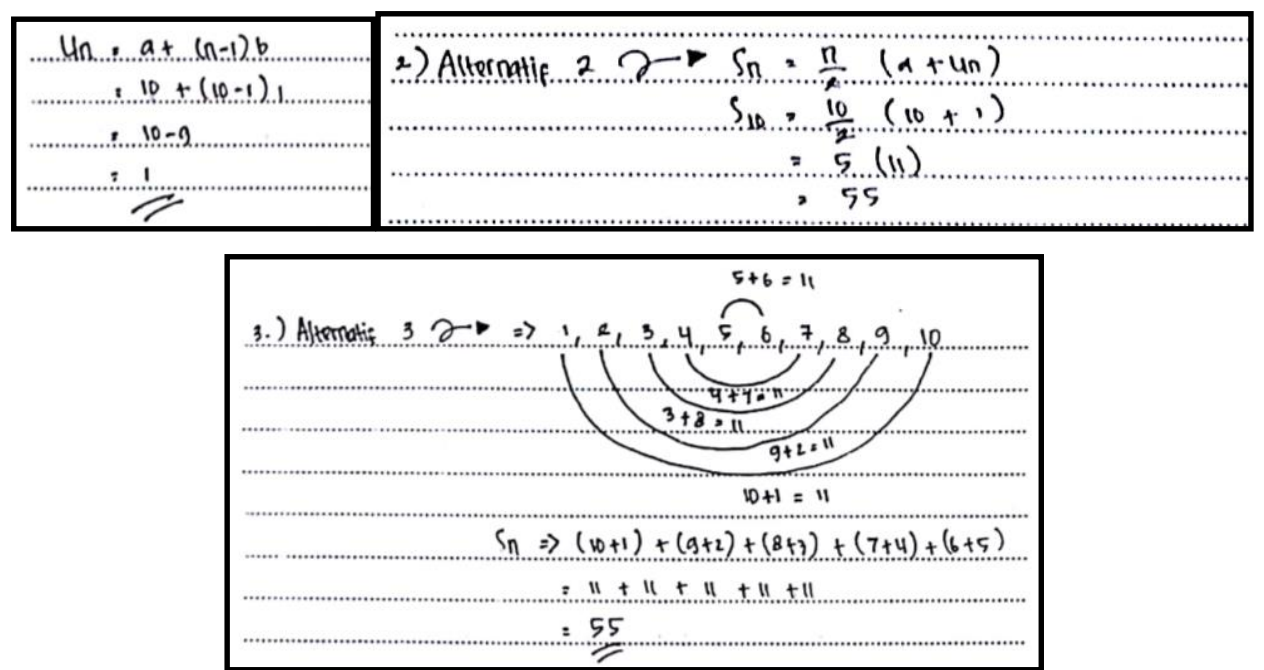

Gambar 10. $S_{2}$ menyelesaikan masalah dengan cara lain

Dari gambar di atas, terlihat bahwa $S_{2}$ mampu menggunakan cara lain dengan hasil yang sama dengan menyelesaikan soal cara pertama, sehingga $S_{2}$ mampu memenuhi indikator berpikir kreatif flexibility.

Langkah pertama yang dilakukan oleh $S_{2}$ ketika menyelesaikan soal nomor 2 terlihat dari hasil pekerjaan berikut ini.

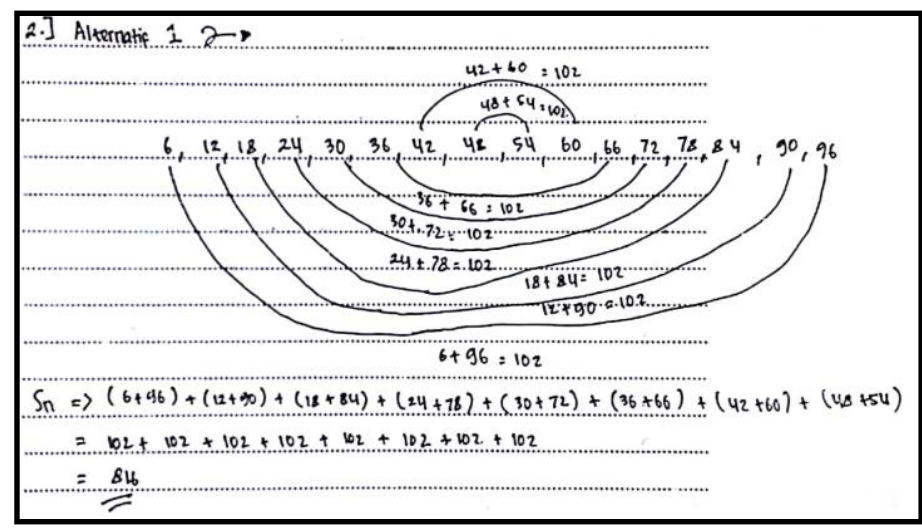

Gambar 11. $S_{2}$ menyelesaikan masalah dengan cara pertama

Dari gambar di atas terlihat bahwa $S_{2}$ langsung menjawab alternatif 1 dengan cara mendaftar anggota bilangan 1-100 yang habis dibagi 6, kemudian menghitungnya secara manual dan menunjukkan hasil yang benar dengan menghitung lancar. Sehingga, $S_{2}$ memenuhi indikator fluency. Selanjutnya, langkah kedua yang dilakukan oleh $S_{2}$ yaitu mencari alternatif jawaban lain. Namun sebelumnya mencari nilai $n$ terlebih dahulu, hal ini terlihat dari hasil pekerjaan berikut ini. 

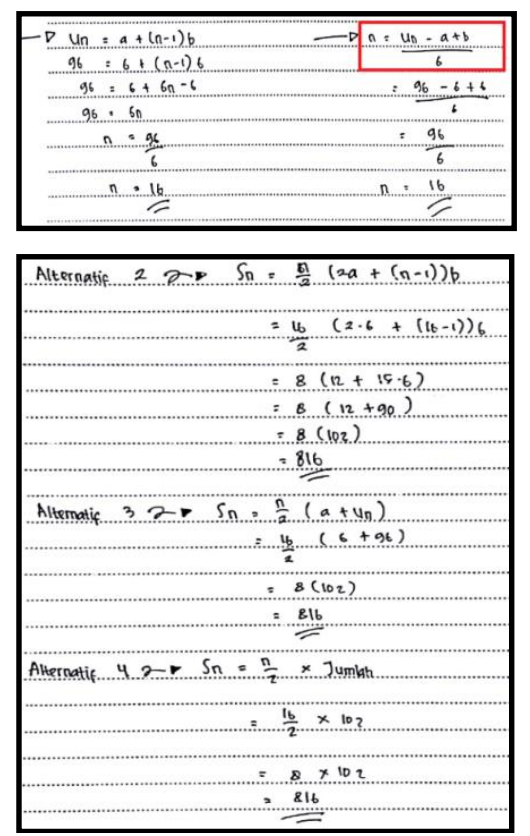

Gambar 12. $S_{2}$ menyelesaikan masalah dengan cara lain

Dari gambar tersebut, hasil pekerjaan $S_{2}$ di atas menunjukkan bahwa $S_{2}$ telah mampu menghitung dengan lancar, sehingga $S_{2}$ telah memenuhi indikator berpikir kreatif fluency. $S_{2}$ juga mampu menggunakan cara lain dalam menyelesaikan soal tersebut serta mendapatkan hasil yang tepat dan benar sehingga $S_{2}$ memenuhi indikator berpikir kreatif flexibility serta $S_{2}$ mampu menghasilkan cara baru dalam proses penyelesaian soal. Pada pemikiran baru yang dihasilkan oleh $S_{2}$ bisa dikatakan kebaruan (novelty), karena cara yang digunakan berdasarkan pemikiran $S_{2}$ sendiri dan belum ada subjek lain yang menggunakan cara tersebut. Sehingga, $S_{2}$ dapat memenuhi indikator berpikir kreatif novelty.

3. Subjek ketiga $\left(S_{3}\right)$

Langkah pertama yang dilakukan oleh $S_{3}$ ketika menyelesaikan soal nomor 1 terlihat dari hasil pekerjaan berikut ini.

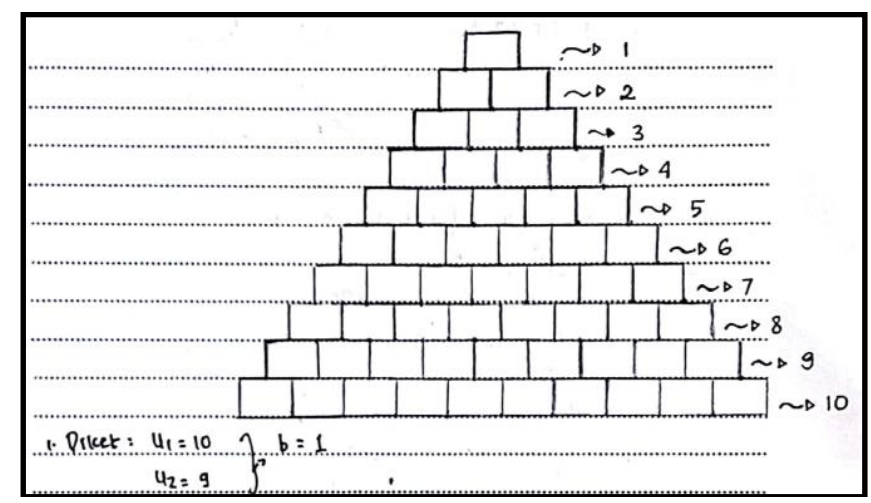

Gambar 13. $S_{3}$ memahami masalah 
Dari gambar di atas, $S_{3}$ sudah dapat memahami masalah dengan menggambar piramida dan menuliskan apa yang diketahui. Setelah $S_{3}$ memahami masalah, $S_{3}$ menyelesaikan masalah dengan cara pertama terlihat pada gambar berikut.

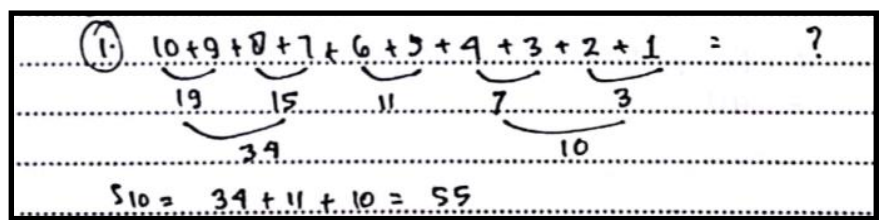

Gambar 14. $S_{3}$ menyelesaikan masalah dengan cara pertama

Dari gambar di atas, terlihat bahwa $S_{3}$ dapat menghitung manual dengan lancar dan memperoleh hasil yang benar, sehingga $S_{3}$ mampu memenuhi indikator berpikir kreatif fluency dalam menyelesaikan soal. Langkah berikutnya yang dilakukan $S_{3}$ yaitu menggunakan cara lain untuk menyelesaikan soal. Hal ini terlihat dari hasil pekerjaan $S_{3}$ berikut ini.



Gambar 15. $S_{3}$ menyelesaikan masalah dengan cara lain

Dari gambar di atas, terlihat bahwa $S_{3}$ dapat menggunakan cara lain yaitu cara kedua dan cara ketiga untuk menyelesaikan soal serta memperoleh hasil yang sama dengan sebelumnya, sehingga $S_{3}$ mampu memenuhi indikator berpikir kreatif flexibility. Dari penyelesaian soal menggunakan cara lain, $S_{3}$ mampu menggunakan idenya untuk menyelesaikan soal dengan rumus baru pada cara yang ketiga dan rumus tersebut berbeda dengan subjek lain. Sehingga, $S_{3}$ dapat memenuhi indikator berpikir kreatif novelty.

Langkah pertama yang dilakukan oleh $S_{3}$ ketika menyelesaikan soal nomor 2 terlihat dari hasil pekerjaan berikut ini.

$$
\text { 2. Plket: } \left.\begin{array}{rl}
u_{1} & =6 \\
u_{2} & =12
\end{array}\right\}, b=6
$$

Gambar 16. $S_{3}$ memahami masalah 
Dari gambar di atas, $S_{3}$ dapat memahami masalah dengan menuliskan apa yang diketahui pada soal dengan cara menghubungkan antara data dengan hal-hal yang belum diketahui. Setelah itu, langkah kedua yang dilakukan $S_{3}$ yaitu merencanakan penyelesaian kemudian menyelesaikan soal sesuai dengan rencana. Hal ini terlihat dari hasil pekerjaan berikut ini.

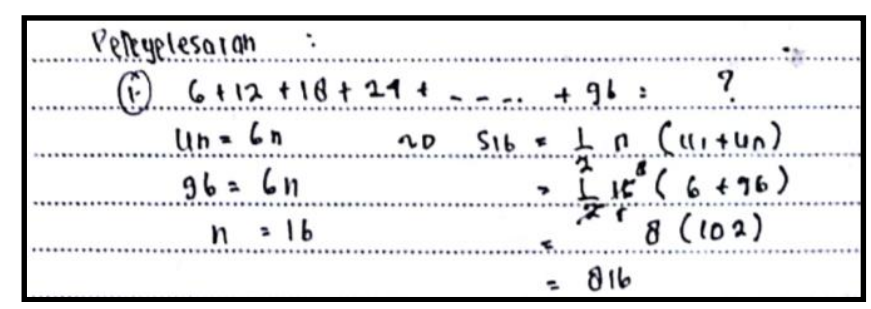

Gambar 17. $S_{3}$ menyelesaikan masalah dengan cara pertama

Dari gambar di atas, terlihat bahwa $S_{3}$ dapat menghubungkan data yang belum diketahui pada soal dan merencanakan penyelesaian dengan menghitung lancar dan hasilnya benar, maka $S_{3}$ telah memenuhi indikator berpikir kreatif fluency. Kemudian, $S_{3}$ mencari alternatif penyelesaian yang terlihat pada gambar berikut.

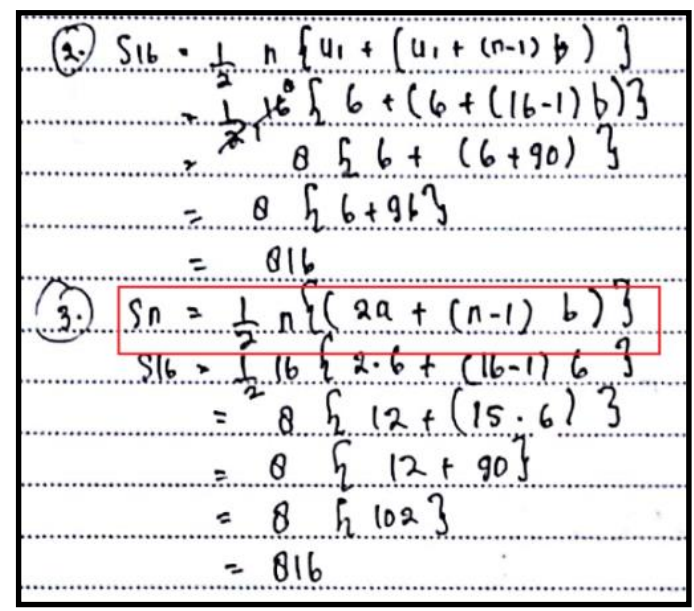

Gambar 18. $S_{3}$ menyelesaikan masalah dengan cara lain

Dari gambar di atas, terlihat bahwa $S_{3}$ dapat menggunakan cara lain untuk menyelesaikan soal serta memperoleh hasil yang benar, sehingga $S_{3}$ mampu menunjukkan indikator berpikir kreatif flexibility. Dari penyelesaian soal menggunakan cara lain, $S_{3}$ mampu menggunakan idenya untuk menyelesaikan dengan rumus yang sebelumnya belum pernah mengetahui dan berbeda dengan subjek lain. Sehingga, $S_{3}$ dapat memenuhi indikator berpikir kreatif novelty.

Dari analisis ketiga subjek di atas, pencapaian indikator berpikir kreatif disajikan dalam bentuk tabel sebagai berikut. 
Tabel 1. Pencapaian Indikator Berpikir Kreatif

\begin{tabular}{|c|c|c|}
\hline \multirow{2}{*}{ Subjek } & \multicolumn{2}{|c|}{ Pencapaian Indikator Berpikir Kreatif } \\
\hline & Soal nomor 1 & Soal nomor 2 \\
\hline$S_{1}$ & $\begin{array}{ll}\text { - } & \text { Kefasihan (fluency) } \\
\text { - } & \text { Keluwesan (flexibility) }\end{array}$ & $\begin{array}{ll}\text { - } & \text { Kefasihan (fluency) } \\
\text { - } & \text { Keluwesan (flexibility) }\end{array}$ \\
\hline$S_{2}$ & $\begin{array}{ll}\text { - } & \text { Kefasihan (fluency) } \\
\text { - } & \text { Keluwesan (flexibility) }\end{array}$ & $\begin{array}{ll}\text { - } & \text { Kefasihan (fluency) } \\
\text { - } & \text { Keluwesan (flexibility) } \\
\text { - } & \text { Kebaruan (novelty) }\end{array}$ \\
\hline$S_{3}$ & $\begin{array}{ll}\text { - } & \text { Kefasihan (fluency) } \\
\text { - } & \text { Keluwesan (flexibility) } \\
\text { - } & \text { Kebaruan (novelty) }\end{array}$ & $\begin{array}{ll}\text { - } & \text { Kefasihan (fluency) } \\
\text { - } & \text { Keluwesan (flexibility) } \\
\text { - } & \text { Kebaruan (novelty) }\end{array}$ \\
\hline
\end{tabular}

Dari tabel tersebut, dapat dilihat bahwa indikator kemampuan berpikir kreatif kefasihan (fluency) dan keluwesan (flexibility) dapat dipenuhi oleh subjek secara keseluruhan. Namun, untuk indikator utama yang merupakan ciri utama dalam berpikir kreatif berupa kebaruan (novelty) pada kedua soal hanya dipenuhi oleh subjek ketiga. Subjek kedua dapat memenuhi kebaruan dalam merencanakan penyelesaian pada soal nomor 2 saja. Namun secara keseluruhan indikator berpikir kreatif yang digunakan peneliti dapat dipenuhi oleh subjek penelitian yang dipilih.

Subjek pertama dalam menyelesaikan soal nomor 1 dan 2 menggunakan 3 cara. Cara pertama mencari $S n$ menggunakan rumus $S n=\frac{n}{2}(2 a+(n-1) b)$ dan mencari nilai $n$ menggunakan rumus $U_{n}=a+(n-1) b$, dapat menghitung secara lancar dan mendapatkan hasil yang benar sehingga memenuhi indikator berpikir kreatif fluency, kemudian mencari alternatif penyelesaian lain yaitu cara kedua dan ketiga menggunakan cara bilangan (numerik) dan cara manual. Hasil yang diperoleh pada penghitungan cara kedua dan ketiga sama dengan cara pertama, maka subjek pertama memenuhi indikator berpikir kreatif flexibility. Karena tidak ada rumus baru yang dihasilkan dari idenya sendiri, maka subjek pertama belum bisa memenuhi indikator berpikir kreatif novelty.

Subjek kedua dalam menyelesaikan soal nomor 1 menggunakan 3 cara dan soal nomor 2 menggunakan 4 cara. Cara pertama pada soal nomor 1 menggunakan rumus $S n=\frac{n}{2}(2 a+(n-1) b)$ dapat menghitung secara lancar dan mendapatkan hasil yang benar sehingga memenuhi indikator berpikir kreatif fluency, kemudian cara yang kedua mencari nilai $U_{n}$ terlebih dahulu menggunakan rumus $U_{n}=a+(n-1) b$ untuk 
mencari $S n=\frac{n}{2}\left(a+U_{n}\right)$ dan cara yang ketiga menghitung secara manual. Dari cara kedua dan ketiga, hasilnya sama dengan cara yang pertama. Sehingga, subjek kedua memenuhi flexibility. Sedangkan pada soal nomor 2, ketiga cara yang digunakan sama dengan nomor 1 ditambah dengan rumus $S n=\frac{n}{2} \times$ Jumlah dan menghitung nilai $n$ dengan menggunakan rumus $n=\frac{U_{n}-a+b}{6}$. Rumus tersebut dihasilkan dari ide subjek sendiri yang sebelumnya belum pernah terpikirkan dan berbeda dengan subjek lain, sehingga subjek kedua memenuhi indikator berpikir kreatif novelty pada soal nomor 2 .

Subjek ketiga dalam menyelesaikan soal nomor 1 dan soal nomor 2 menggunakan 3 cara. Untuk cara pertama pada nomor 1 menghitung jumlah secara manual dengan lancar dan benar, sehingga subjek ketiga memenuhi indikator berpikir kreatif fluency. Kemudian cara yang kedua mencari nilai $n$ terlebih dahulu menggunakan rumus $U_{n}=$ $U_{1}+(n-1) b$ untuk menghitung $S n=\frac{1}{2} n\left(U_{1}+U_{n}\right)$ dan cara yang ketiga menggunakan rumus $S n=\frac{1}{2} n\left(U_{1}+\left(U_{1}-(n-1) b\right)\right.$. Hasil yang diperoleh pada penghitungan cara kedua dan ketiga sama dengan cara pertama, maka subjek ketiga memenuhi indikator berpikir kreatif flexibility. Sedangkan pada soal nomor 2, langkah pertama mencari $n$ menggunakan $U_{n}=6 n$, selanjutnya mencari jumlahnya dengan rumus $S n=\frac{1}{2} n\left(U_{1}+U_{n}\right)$. Kedua menggunakan rumus $S n=\frac{1}{2} n\left(U_{1}+\left(U_{1}+\right.\right.$ $(n-1) b)$. Ketiga menggunakan rumus $S n=\frac{1}{2} n(2 a+(n-1) b$. Dari hasil pekerjaan subjek ketiga, rumus $S n=\frac{1}{2} n\left(U_{1}+\left(U_{1}-(n-1) b\right)\right.$ pada nomor 1 dan $S n=$ $\frac{1}{2} n\left(U_{1}+\left(U_{1}+(n-1) b\right)\right.$ pada nomor 2 , dihasilkan dari pemikiran subjek sendiri dan tidak ada subjek lain yang menggunakan rumus tersebut maka subjek ketiga memenuhi indikator berpikir kreatif novelty pada kedua soal.

Penelitian yang dilakukan oleh Izaelatul Laela tahun 2017 dengan judul "Tingkat Kemampuan Berpikir Kreatif Siswa dalam Menyelesaikan Soal Barisan dan Deret Kelas XI APK 3 SMK PGRI 1 Tulungagung Tahun Ajaran 2016/2017”. Dalam penelitiannya, subjek dengan kemampuan matematika tinggi hanya memenuhi indikator berpikir kreatif fluency dan flexibility saja, subjek penelitiannya belum menemukan novelty dalam menyelesaikan soal. Sedangkan dalam penelitian ini, ada subjek yang mampu menunjukkan novelty dalam menyelesaikan soal. Dalam penelitian Siswono tahun 2011 
dengan judul "Level of student's creative thinking in classroom mathematics". Dalam penelitiannya, Siswono menggunakan indikator berpikir kreatif matematika yang sama dengan penelitian ini yaitu fluency, flexibility dan novelty.

Penelitian lain yaitu penelitian yang dilakukan oleh Ranak Lince tahun 2016 yang berjudul "Creative Thinking Ability to IncreaseStudent Mathematical of Junior High School by Applying Models Numbered Heads Together" menunjukkan bahwa menilai berpikir kreatif siswa melalui pembelajaran NHT (Numbered Heads Together) yang melibatkan kelompok dalam suatu pembelajaran. Sedangkan dalam penelitian ini untuk menggali berpikir kreatif, subjek diberikan masalah yang berbasis open-ended. Subjek hanya menyelesaikan masalah, namun diharapkan menyelesaikan masalah dengan beberapa alternatif jawaban, karena soal yang disajikan berbasis open-ended dimana soal tersebut di desain memiliki banyak cara untuk menyelesaikan dan hasilnya sama.

Penelitian oleh Febriyanti, Hobri \& Setiawani tahun 2016 yang berjudul "Tingkat Berpikir Kreatif Siswa Kelas VII dalam Menyelesaikan Soal Open-Ended pada Sub Pokok Bahasan Persegi Panjang dan Persegi”. Dalam penelitian yang dilakukan Febriyanti dkk menggunakan soal open-ended dengan materi persegi panjang dan persegi yang diukur kreatifnya menggunakan indikator fluency, flexibility dan originality, sedangkan dalam penelitian ini menggunakan materi barisan dan deret aritmatika yang diukur menggunakan indikator fluency, flexibility dan novelty.

\section{SIMPULAN DAN SARAN}

Sesuai dengan hasil pembahasan dan temuan-temuan yang diperoleh selama proses penelitian diperoleh kesimpulan bahwa, (1) hasil pekerjaan seluruh pada kedua soal tidak menunjukkan adanya coretan dan kesalahan dalam menghitung. Sehingga, seluruh subjek penelitian mampu menghitung dengan lancar dan hasil penghitungannya tepat, maka indikator berpikir kreatif fluency mampu dipenuhi seluruh subjek penelitian, (2) hasil pekerjaan seluruh subjek pada kedua soal menunjukkan lebih dari satu cara dan hasil antara satu cara dengan cara yang lainnya sama. Sehingga, seluruh subjek penelitian mampu memenuhi indikator berpikir kreatif flexibility dalam menyelesaikan soal barisan dan deret aritmatika, (3) hasil pekerjaan subjek pertama tidak menunjukkan adanya kebaruan, karena rumus yang digunakan bersifat umum. Pada hasil pekerjaan subjek kedua menunjukkan kebaruan pada rumus $n=\frac{U_{n}-a+b}{6}$ dan hasil pekerjaan 
subjek ketiga menunjukkan kebaruan pada rumus $S n=\frac{1}{2} n\left(U_{1}+\left(U_{1}-(n-1) b\right)\right.$ dan rumus $S n=\frac{1}{2} n\left(U_{1}+\left(U_{1}+(n-1) b\right)\right.$. Sehingga, novelty dipenuhi oleh subjek kedua dan ketiga.

Kemampuan berpikir kreatif merupakan hal yang penting diberikan dalam pembelajaran matematika menggunakan metode pembelajaran yang bersifat inovatif, maka dapat disampaikan saran untuk peneliti selanjutnya yaitu dapat dijadikan sebagai bahan kajian pada penelitian lanjutan sehingga dapat memberi kontribusi bagi upaya peningkatan kualitas pendidikan. Pada penelitian ini hanya mampu memberi sedikit gambaran mengenai berpikir kreatif dalam menyelesaikan salah satu materi matematika SMP yaitu barisan dan deret aritmatika dengan metode open-ended. Oleh karena itu, penelitian lanjutan sangat diperlukan tentunya dengan inovasi yang berbeda untuk mengetahui berpikir kreatifnya siswa.

\section{DAFTAR PUSTAKA}

Fardah, D.K. 2012. Analisis Proses dan Kemampuan Berpikir Kreatif Siswa dalam Matematika Melalui Tugas Open-Ended. Jurnal Kreano Vol 3, No 2.

Febriyanti, U. A., Hobri., \& Setiawani, S. 2016. Tingkat Berpikir Kreatif Siswa Kelas VII dalam Menyelesaikan Soal Open-Ended pada Sub Pokok Bahasan Persegi Panjang dan Persegi. Jurnal Edukasi UNEJ, Vol 3: 5-8.

Firdausi, Y. N., Asikin, M. \& Wuryanto. 2018. Analisis Kemampuan Berpikir Kreatif Siswa Ditinjau dari Gaya Belajar pada Pembelajaran Model Eliciting Activities (MEA). Prisma 1, Prosiding Seminar Nasional Matematika. 239-247. Diakses di https://journal.unnes.ac.id/sju/index. php/prisma/

Kang Sup, Lee., Dong-jou, Hwang., \& Jong Jin, Seo. 2003. A Development of The Test for Mathematical Creative Problem Solving Ability. Journal of the Korea Society of Mathematical Education Series D: Research in Mathematical Education Vol 7: 163-189.

Koriyah, V. N., \& Harta, I. 2015. Pengaruh Open-Ended terhadap Prestasi Belajar, Berpikir Kritis dan Kepercayaan Diri Siswa SMP. PYTHAGORAS: Jurnal Pendidikan Matematika Vol 10: 95-105.

Laela, I. 2017. Tingkat Kemampuan Berpikir Kreatif Siswa dalam Menyelesaikan Soal Barisan dan Deret Kelas XI APK 3 SMK PGRI 1 Tulungagung Tahun Ajaran 2016/2017. Skripsi tidak dipublikasikan. Tulungagung: Institut Agama Islam Negeri (IAIN) Tulungagung. 
Lince, R. 2016. Creative Thinking Ability to Increase Student Mathematical of Junior High School by Applying Models Numbered Heads Together. Journal of Education and Practice Vol 7: 206-212.

Mepnews. 2016. Peringkat Pisa Indonesia Naik tapi Masih Sangat Rendah (Online). (http://mepnews.id/2016/12/07/peringkat-pisa-indonesia-naiktapi-masih-sangatrendah/,diakses 17 November 2017).

Mrayyan, S. 2016. Investigating Mathematics Teachers Role to Improve Students Creative Thinking. American Journal of Educational Research Vol 4: 82-90.

Siswono, T. Y. E. 2011. Level of Student's Creative Thinking in Classroom Mathematics. Educational Research and Review Vol 6: 548-553.

Sugiyono. 2012. Metode Penelitian Kuantitatif, Kualitatif dan $R$ \& D. Bandung: Alfabeta.

Widoyoko, S. E. P. 2017. Teknik Penyusunan Instrumen Penelitian. Yogyakarta: Pustaka Pelajar. 